\title{
Monoclonal Antibodies to the Dentate Gyrus: Immunocytochemical Characterization and Flow Cytometric Analysis of Hippocampal Neurons Bearing a Unique Cell-Surface Antigen
}

\author{
Joseph R. Moskal* and Anne E. Schaffner $\dagger$ \\ *Laboratory of Cell Biology, NIMH, and †Laboratory of Neurophysiology, NINCDS, NIH, Bethesda, MD 20892
}

\begin{abstract}
Monoclonal antibodies were generated using 5 d neonatal rat dentate gyrus as immunogen. One antibody of this panel, G6E3, recognized a cell-surface protein with an $M_{\mathrm{r}}=43,000$ that was found only in the nervous system. The antigen was expressed as early as embryonic day 13 in the rat in both the brain and spinal cord. In the adult rat the antigen was demonstrated immunohistochemically to be restricted to dentate gyrus granule, hippocampal pyramidal, and cerebellar Purkinje neurons. These results suggested that the antigen recognized by $\mathrm{G6E3}$ may be developmentally regulated. Moreover, G6E3 did not appear to bind to mitotic cells, implying that the antigen was expressed after the terminal mitosis. The antibody also bound to hippocampal and cerebellar cells from mouse brain, including the reeler mutant, and rat hippocampal neurons in vitro. Doublelabeling experiments performed on embryonic rat hippocampal cultures with G6E3 and antibodies to neuron-specific enolase (NSE) or anti-glutamic acid decarboxylase (GAD) revealed that only NSE-positive cells were immunoreactive for G6E3 and, while G6E3-positive cells were decorated with GAD-positive boutons, their cell bodies did not contain GAD. With the use of a fluorescence-activated cell sorter it was possible to analyze the immune reaction on embryonic and postnatal hippocampal cells and to sort G6E3-positive neurons for maintenance in vitro.
\end{abstract}

The molecular mechanisms underlying appropriate synapse formation have been postulated to involve cell-surface recognition molecules (Boyse and Cantor, 1979; Hood et al., 1977; Roseman, 1974; Sperry, 1963; Tyler, 1947; Weiss, 1947). The identification of such molecules and the elucidation of the mechanisms that regulate their expression could provide a molecular foundation for examining the neuronal changes that are thought to take place during information processing. The strategy of generating monoclonal antibodies to a specific tissue or brain structure has been fruitful in identifying regionally restricted cell-surface antigens (Barnstable, 1980; Bartlett et al., 1981; Cohen and Selvendran, 1981; Hawkes et al., 1982; McKay and Hockfield, 1982; Schachner, 1982) and thereby lending support to the notion that molecules exist that could be involved in the establishment of proper neuronal circuitry.

We have generated a panel of monoclonal antibodies to the developing rat dentate gyrus of the hippocampal formation. Various properties are attributed to this structure that make it possible to study the role that identified antigens might play in establishing proper neuronal position and synaptic connections.

\footnotetext{
Received Aug. 29, 1985; revised Jan. 10, 1986; accepted Jan. 13, 1986.

We thank Miklos Palkovits, Eva Mezey, Rebecca Pruss, Michael Brownstein, and Jeffery Barker for their advice and helpful discussions. We thank Veronica Smallwood and Wayne Kell for excellent technical assistance.

Correspondence should be addressed to Joseph R. Moskal, Laboratory of Cell Biology, Building 36, Rm. 3A-17, NIMH, Bethesda, MD 20892.

Copyright (C) 1986 Society for Neuroscience 0270-6474/86/072045-09\$02.00/0
}

For example, the dentate gyrus is formed by the migration of granule cells along several morphogenetic axes (Schlessinger et al., 1975) and greater than $80 \%$ of these cells are generated postnatally, after their synaptic targets (hippocampal pyramidal neurons) are already in place (Bayer, 1980; Bayer and Altman, 1974; Bayer et al., 1982). The ability to induce new synapse formation by lesion is a well-documented process in the hippocampal formation. The morphological changes that accompany this process have becn extensively studied because of the clearly defined, laminar organization of hippocampal neurons (Cotman, 1976; Cotman and Nadler, 1978).

In this report we demonstrate that one monoclonal antibody, G6E3, recognizes a cell-surface protein that is found only on hippocampal pyramidal, dentate gyrus granule and cerebellar Purkinje neurons in the adult rat. This antigen is expressed on hippocampal neurons in vitro and is found in several mouse strains, including the reeler mutant. Previously, Kapatos et al. (1983) used a monoclonal antibody in conjunction with cell sorting to isolate a subpopulation of embryonic spinal cord neurons. We have used G6E3 and a fluorescence-activated cell sorter to analyze the immune reaction on embryonic and postnatal hippocampal cells and, in preliminary experiments, to isolate hippocampal neurons for cell culture.

\section{Materials and Methods}

\section{Monoclonal antibody production and screening}

Five-day postnatal rat dentate gyri were removed by the micropunch method of Palkovits and Brownstein (1983). The tissue was immediately homogenized in PBS at $4^{\circ} \mathrm{C}$ and injected intraperitoneally into $\mathrm{Balb} / \mathrm{c}$ mice. An average of $50 \mathrm{mg}$ wet weight of tissue was injected per mouse. This procedure was repeated 4 times over 2 months. Monoclonal antibodies were generated by conventional techniques using NS-1 as the parent myeloma cell line (Galfre et al., 1977; Kohler and Milstein, 1976). The antibodies were screened against unfixed, frozen tissue that had been cryoprotected by preincubation with a graded series $(10-30 \%)$ of sucrose in Dulbecco's modified Eagle's medium (high glucose; Gibco, Grand Island, NY). Ten micron sections (cut with a cryostat and placed on collagen-coated glass microscope slides) were incubated for $24 \mathrm{hr}$ at $4^{\circ} \mathrm{C}$ with G6E3 hybridoma conditioned tissue culture medium (RPMI plus $15 \%$ fetal bovine serum), tissue culture medium alone as control, or medium containing the nonspecific $\mathrm{IgG}_{1}$ monoclonal antibody P3X63Ag8 as a second control. Antibody binding was visualized by incubating sections with a fluoresceinated rabbit anti-mouse IgG (Dako Corp., Santa Barbara, CA) diluted 1:50 with PBS. Antibodies were further screened with $50 \mu \mathrm{m}$ vibratome sections from rat brains that had been perfused with a solution of ice-cold $0.2 \%$ picric acid and $4 \%$ paraformaldehyde in $0.167 \mathrm{M}$ sodium phosphate buffer, $\mathrm{pH} 7.0$. In these experiments, the secondary antibody was a peroxidase-conjugated goat anti-mouse IgG (Boehringer-Mannheim, Indianapolis, IN) diluted 1:100 in PBS and visualized with diaminobenzidine following the method described by Kiss et al. (1984). Subtyping of the antibodies was done using a Subtype Immunoglobulin Kit from Boehringer-Mannheim. 


\section{Primary hippocampal cultures}

Hippocampi were removed from 19-20 d rat embryos, mechanically dissociated, and plated at a density of $0.5-1.0 \times 10^{6}$ cells per $35 \mathrm{~mm}$, collagen-coated dish. Plating medium consisted of minimal essential medium with Earle's salts (MEM), glucose (final concentration, $30 \mathrm{mM}$ ), sodium bicarbonate (final concentration, $38 \mathrm{mM}$ ) (Advanced Biotechnologies, Rockville, MD), $5 \%$ fetal bovine serum, $5 \%$ horse serum (both from Hazelton Dutchland, Inc., Denver, PA), and serum-free additives. The serum-free additives were prepared by a modification of Romijn et al. (1984) and were composed of glutamine (final concentration, 2 $\mathrm{mM}$ ), insulin $(5 \mu \mathrm{g} / \mathrm{ml})$ (Collaborative Research, Lexington, MA), corticosterone $(100 \mathrm{ng} / \mathrm{ml})$, sodium selenite $\left(3 \times 10^{-8} \mathrm{M}\right)$, transferrin $(50 \mu \mathrm{g} /$ $\mathrm{ml}$ ), and thyroxine $(5 \mathrm{ng} / \mathrm{ml}$ ) (all from Sigma, St. Louis, MO). After 4 $6 \mathrm{~d}$, when dividing cells had grown to confluency, the medium was changed to MEM, serum-free additives, $5 \%$ horse serum, fluorodeoxyuridine (FUDR; final concentration, $10^{-5} \mathrm{M}$ ), and uridine (U; final concentration, $10^{-4} \mathrm{M}$ ) (both from Sigma) to inhibit further growth of dividing cells. The medium was replaced after 3-4 d and twice weekly thereafter with MEM, serum-free additives, and horse serum without FUDR or U. Cultures were maintained in a humidified atmosphere of 92\% air : $8 \%$ carbon dioxide at $36.5^{\circ} \mathrm{C}$ (Segal, 1983).

\section{Immunohistochemistry of cultured cells}

Two- to 3-week-old, unfixed, hippocampal cultures were stained with G6E3 conditioned medium (CM) or ascites fluid for $45 \mathrm{~min}$ to $1 \mathrm{hr}$ on ice. Ascites fluid was diluted 1:10 to 1:50 in Hank's balanced salt solution (Gibco) with $10 \mathrm{~mm}$ HEPES, and $1 \%$ bovine serum albumin (HBSA). Conditioned medium was used full strength or diluted 1:1 in HBSA. After rinsing in HBSA, cultures were incubated for $30 \mathrm{~min}$ on ice with a fluoresceinated secondary antibody [affinity-purified $\mathrm{F}\left(\mathrm{ab}^{\prime}\right)_{2}$ goat anti-mouse IgG; Jackson ImmunoResearch, Avondale, PA] diluted $1: 50$ or $1: 100$ in HBSA. It was necessary to stain unfixed cultures on ice to preserve antigenicity and prevent patching and capping of antigenantibody complexes. After rinsing in HBSA, cultures were viewed immediately in a Zeiss Photomicroscope III (Baltimore Instruments, Baltimore, MD). For double-labeling experiments, cultures were fixed after G6E3 staining with $4 \%$ paraformaldehyde in $0.1 \mathrm{M}$ phosphate buffer, pH 7.3, at $4^{\circ} \mathrm{C}$ for $1 \mathrm{hr}$. Cultures were then incubated with anti-NSE (Marangos et al., 1975; a gift from Dr. Paul Marangos) antibodies followed by an unlabeled sheep anti-rabbit secondary antibody. Specific staining was visualized by the peroxidase-antiperoxidase (PAP) method of Sternberger (1974). Cultures were also incubated with anti-GAD antibodies (Oertel et al., 1981; a gift from Dr. Wolfgang Oertel) followed by a rhodaminated rabbit anti-sheep secondary antibody (from Jackson ImmunoResearch as above). For double staining with G6E3 and antiNSE it was necessary to photograph G6E3 positive cells after fixation, since the diaminobenzidine reaction product occluded the fluorescent staining. The same fields were rephotographed after PAP staining.

\section{Flow cytometric analysis and sorting}

Embryonic or early postnatal hippocampal tissue from rat pups was dissociated without the use of enzymes in Puck's saline with added glucose and sucrose (made from a 20X D, concentrate from Colorado Serum Co., Denver, CO, with $10 \mathrm{~mm}$ HEPES, $17 \mathrm{~mm}$ glucose, and 22 mM sucrose). The cell suspensions were resuspended in $C M$ or ascites fluid at a concentration of not more than $2 \times 10^{6}$ cells per ml. (Antibody concentrations and buffer were identical to those used for cell culture staining.) Controls were incubated in similar dilutions of $\mathrm{CM}$ or ascites

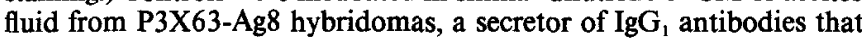
do not bind to neural tissues (Trisler et al., 1981) or with HBSA alone. Tubes containing the cell suspensions were incubated for $45 \mathrm{~min}$ on ice to prevent patching and capping of antigen-antibody complexes. Cells were then centrifuged at $300 \times g$ for $5 \mathrm{~min}$, washed twice with $10 \mathrm{ml}$ of HBSA, and resuspended in a 1:50 dilution in HBSA of a fluoresceinated secondary antibody (Jackson ImmunoResearch, as above). After staining in secondary antibody for $30 \mathrm{~min}$ on ice, the cells were centrifuged and washed as before and filtered through $62 \mu \mathrm{m}$ Nitex to remove clumps. These staining methods were developed in collaboration with Kapatos et al. (1983). Cells were analyzed and sorted in a Becton-Dickinson FACS 440 equipped with a $5 \mathrm{~W}$ argon-ion laser operating at $488 \mathrm{~nm}$ with an output of $400 \mathrm{~mW}$. Sorting rate was less than 2000 events $/ \mathrm{sec}$. Sorted cells were collected into $15 \mathrm{ml}$ centrifuge tubes precoated with Sigmacote (a siliconizing agent from Sigma) containing HBSA. Sorted cells were centrifuged at $300 \times g$ for $5 \mathrm{~min}$ and resus- pended in plating medium containing heat-inactivated sera (to avoid complement-mediated cytotoxicity). Cells were plated into $35 \mathrm{~mm}$ petri dishes that had been precoated with collagen or poly(L-lysine) or contained a confluent layer of non-neuronal cells from the hippocampus or cortex (generated by plating postnatal tissue at very low densities) and maintained under the same conditions as "mixed" hippocampal cultures.

Distributions of counts of cells as a function of their light scatter and fluorescence were constructed as $64 \times 64$ bin histograms. Histograms were made for both experimental and control samples. Difference histograms were made by subtracting corresponding bins in the control histograms from those in the experimental histograms. Negative values were ignored.

\section{${ }^{3} H$-thymidine autoradiography}

Female rats, $20 \mathrm{~d}$ in term, were injected intraperitoneally with $2 \mu \mathrm{Ci}$ / gm body weight of ${ }^{3} \mathrm{H}$-thymidine (New England Nuclear; specific activity $6 \mathrm{Ci} / \mathrm{mmol}$ ) in sterile distilled water. Embryos were delivered and their hippocampi dissected $2.5 \mathrm{hr}$ after injection. Cells were mechanically dissociated and incubated with G6E3 followed by a fluoresceinated secondary antibody as described for cell sorting. After washing with Hank's balanced salt solution (Gibco), the cells were fixed in $4 \%$ formaldehyde at $0^{\circ} \mathrm{C}$ for $1 \mathrm{hr}$. Fixed cells preincubated with G6E3 or secondary antibody alone (controls) were placed on slides, dried, coated with Ilford $\mathrm{K} 5$ emulsion (1:1 dilution in distilled water), and developed at $4^{\circ} \mathrm{C}$ for $10-14 \mathrm{~d}$. Slides were developed in D-19 (Kodak) for 4 min, fixed for $10 \mathrm{~min}$, rinsed, and mounted in a 1:1 solution of PBS : glycerol saturated with $n$-propyl gallate (Giloh and Sedat, 1982). This radiographic technique was essentially a modification of Koulakoff et al. (1983).

\section{G6E3 radioimmunoassay}

Tissues to be assayed (reeler mice and their appropriate controls were obtained from Jackson Laboratories, Bar Harbor, ME) were dissected and homogenized in PBS containing $1 \mathrm{~mm}$ phenylmethylsulfonylfluoride and frozen. Assays were performed in 96 well microtiter plates (Dynatech, Alexandria, VA). Tissues $(0.1-0.5 \mathrm{mg}$ protein/well was found to be in the linear range) were first washed 3 times with PBS- $10 \%$ fetal bovine serum $\left(4^{\circ} \mathrm{C}\right)$ followed by incubation with $\mathrm{G} 6 \mathrm{E} 3$ for $60 \mathrm{~min}$ at $4^{\circ} \mathrm{C}$. G6E3 ascites fluid diluted 1:100 was found to be saturating under these conditions. The secondary antibody, a goat anti-mouse ${ }^{125} \mathrm{I}-\mathrm{F}\left(\mathrm{ab}^{\prime}\right)_{2}$ (50-100,000 cpm; Amersham, Arlington, IL) at a concentration of 440 nM was then added, and incubations were continued for $30 \mathrm{~min}$ at $4^{\circ} \mathrm{C}$. While $440 \mathrm{nM} F\left(\mathrm{ab}^{\prime}\right)_{2}$ prepared with unlabeled goat anti-mouse $\mathrm{F}\left(\mathrm{ab}^{\prime}\right)_{2}$ (Cappel, West Chester, PA) was not saturating, the samc proportion of binding was found at higher concentrations and thus was chosen for the sake of economy. As a nonspecific control, P3X63-Ag8 ascites fluid was used in parallel experiments. The values obtained with $\mathrm{P} 3 \mathrm{X} 63$-Ag8 were subtracted from those obtained with G6E3 to obtain specific binding. Protein determinations were performed by the method of Bradford (1976).

\section{Identification of G6E3-specific proteins by immunoblot analysis}

Freshly dissected adult rat hippocampus or cerebellum was subjected to SDS-PAGE according to the method of Laemmli (1970). Proteins were transferred to nitrocellulose membranes according to the method of Towbin et al. (1979), and the detection of G6E3-specific protein binding was accomplished by the method of Batteiger et al. (1982). The secondary antibody was a peroxidase-conjugated goat anti-mouse IgG (Miles Laboratories, Inc., Elkhart, IN; 1:500 dilution), and 4-chloronaphthol was used as visualizer.

\section{Results}

The monoclonal antibody $\mathrm{G} 6 \mathrm{E} 3$ is an $\mathrm{IgG}_{1}$ that recognizes adult rat dentate gyrus granule, hippocampal pyramidal, and cerebellar Purkinje neurons in the adult rat (Fig. 1). The only other staining observed thus far was to some cortical neurons, but this was very faint and not associated with any specific structure or pattern. When glutaraldehyde, paraformaldehyde, or formalin was used as fixative, all G6E3 binding was abolished. However, with a mixture of picric acid and paraformaldehyde, antigenicity was well preserved (Fig. 1d). G6E3 hippocampal 

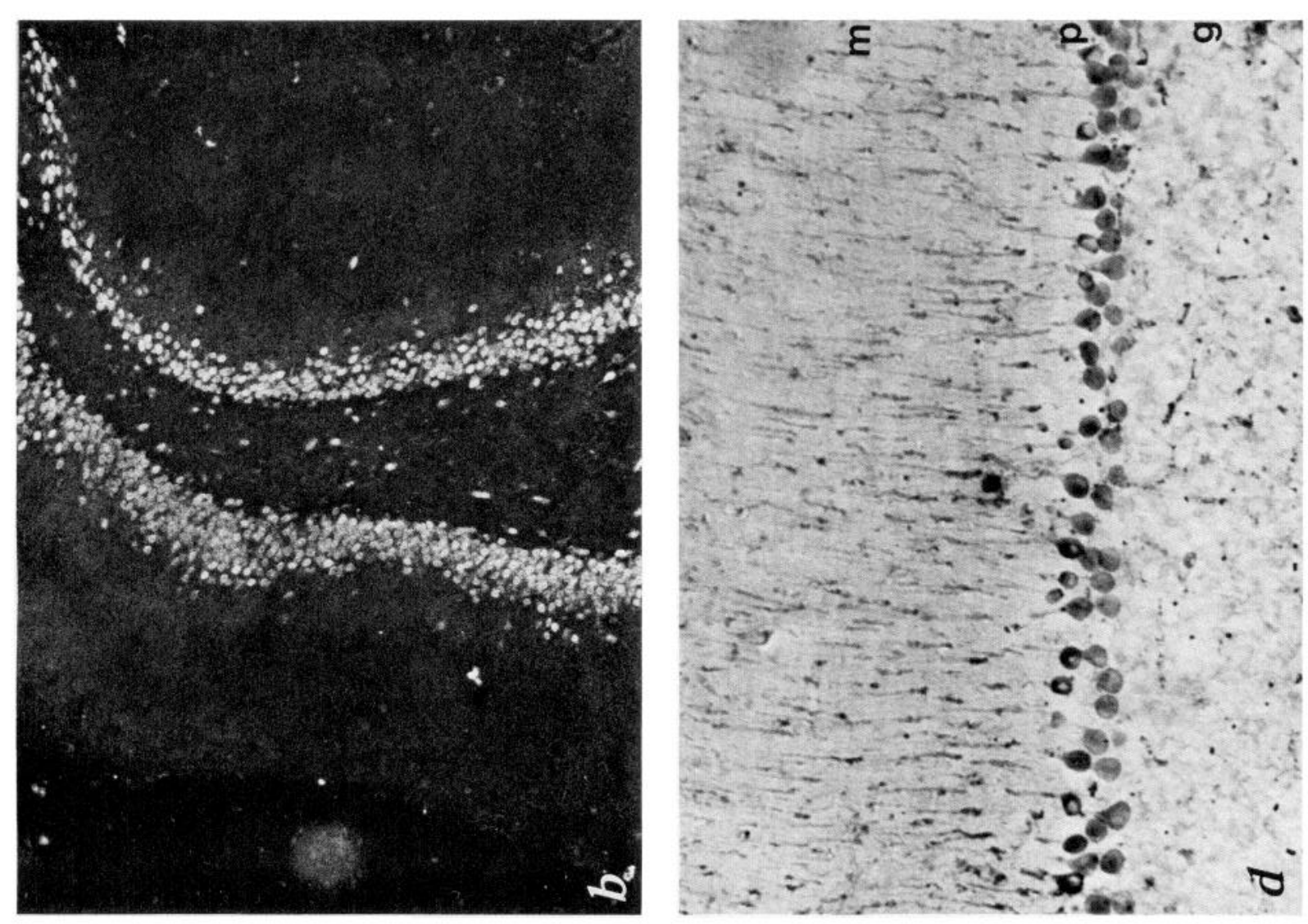

도의

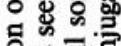

응

통ㅎํำ

要

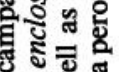

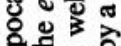

응 홍

武实

둥둥

멸 형

일대웡

药

可马

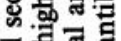

สำ

응흐ㅇㅡㅡㅇ

ơ

तु

돈

응

象管

.

틀

क्ष 政

ㅁํำ
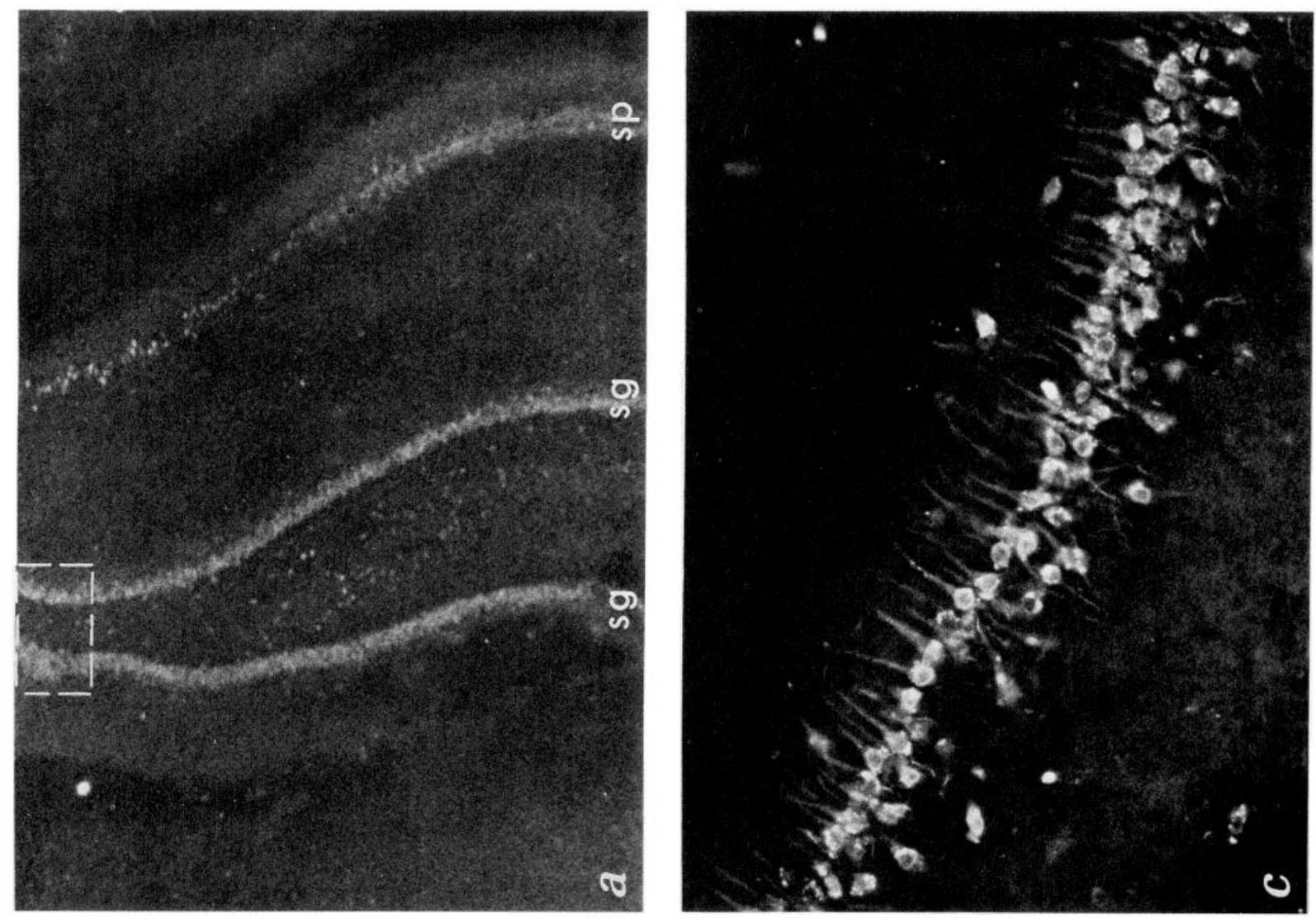

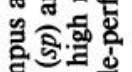

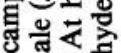

की

刍 읭

‡ a.

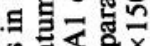

년원

के क्ष

헝

도의

요웡

क⿺辶力.

范苍豆

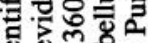

원

至

엉

政

중형. 영.

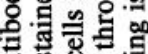

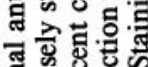

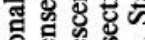

형형혀

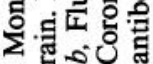
毛 00

芯客宅哥

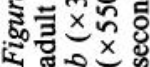




\begin{tabular}{lllll}
\hline \multicolumn{2}{l}{ Table 1. } & \multicolumn{4}{l}{ Developmental localization of G6E3 in the rat } & \\
Age & Tissue & G6E3 & Method & Localization \\
\hline ED 13 & Brain & + & FACS, RIA & \\
& Spinal cord & + & FACS, RIA & \\
ED 19-PN5 & Hippocampus & + & FACS, RIA, IHC & Pyramidal cells, granule cells (?) \\
& Cerebellum & + & FACS, RIA, IHC & External, internal granule layer, \\
& & & & Purkinje cell layer (?) \\
& Cortex & + & FACS, RIA, IHC & Lamellar \\
Adult & Spinal cord & + & FACS, RIA & \\
& Olfactory bulb & + & FACS & \\
& Hippocampus & + & RIA, IHC & Pyramidal and granule cells \\
& Cerebellum & + & RIA, IHC & Purkinje cells \\
& Cortex & $+/-$ & RIA, IHC & Faint staining of some cells \\
& Spinal cord & $+/-$ & RIA & \\
& Olfactory bulb & $+/-$ & RIA, IHC & Faint staining of some cclls \\
& Liver & - & RIA & \\
& Kidney & - & RIA &
\end{tabular}

Abbreviations: ED, embryonic day; PN, postnatal day; FACS, fluorescence-activated cell sorting (analysis); RIA, radioimmunoassay; and $\mathrm{IHC}$, immunohistochemistry.

staining was the same in tissue fixed by this method as in unfixed tissue, ruling out artifactual staining of the latter. G6E3 binding could be detected as early as embryonic day 13 in both the brain and spinal cord. G6E3 binding may be present earlier, but this remains to be determined. We used various biochemical and immunological methods to detect the antigen recognized by G6E3 in various embryonic and postnatal rat tissues. As can be seen in Table 1, its distribution became increasingly restricted with age.

The binding of G6E3 was also studied in primary hippocampal cultures. A typical primary culture of dissociated hippocampal cells is shown in Figure $2 b$. G6E3 stained both cell bodies and processes of subpopulations of living cells in these cultures. The ring of fluorescence around the positively stained cell bodies suggested that G6E3 recognized an antigen $\left(A_{g 6}\right)$ expressed on the cell surface. Figure $2 a$ shows the fluorescence binding pattern of G6E3 in a 19-20 d embryonic rat brain hippocampal formation. Evidently the antibody binds to pyramidal and granule cells at this stage of devclopment. While it is straightforward to identify hippocampal cells stained in sections, this is not the case for cells dissociated from brain and maintained in culture. However, in cultures generated from the embryonic hippocampus, G6E3 bound only to cells that costained with antibodies to NSE, indicating that it is specific to nerve cells (Schmechel et al., 1980) (Fig. 2, c, d). G6E3 recognized an average of 55\% of the NSE-positive cells in these cultures. Colocalization studies with G6E3 and anti-GAD antibodies are shown in Figure 2, $e$ and $f$, respectively. Although only approximately $5 \%$ of G6E3positive cells stained for GAD intracellularly (after an overnight treatment with $10^{-9} \mathrm{M}$ colchicine), GAD-positive boutons could be seen decorating virtually all of the G6E3-positive cells. In vivo, both pyramidal and granule neurons receive GABAergic innervation (Kosaka et al., 1984). Thus, these data support the idea that G6E3 binds to granule and/or pyramidal neurons in culture, but it is not possible at this time to differentiate these 2 cell types unambiguously in vitro.

Because G6E3 binds to neurons very early in development and the formation of the dentate gyrus extends into the postnatal period, a ${ }^{3} \mathrm{H}$-thymidine experiment was performed to determine if G6E3 bound to dividing cells in 19-20 d rat embryos (the same age used for generating hippocampal cultures and cell suspensions for sorting). Since thymidine uptake occurs within 30 min (Schlessinger et al., 1978), a circulation time of $2.5 \mathrm{hr}$ was adequate to label all cells in S-phase at the time of injection. It can be seen in Figure 3, $a$ and $b$, that both G6E3-positive cells and cells incorporating ${ }^{3} \mathrm{H}$-thymidine were present. However, the 2 labels were mutually exclusive: G6E3 staining was only found on cells that did not incorporate radiolabel. Approximately $12 \%$ of the cells examined incorporated ${ }^{3} \mathrm{H}$-thymidine (64 positive cells out of 560 cells examined). Between 10 and $15 \%$ of the cells that did not incorporate ${ }^{3} \mathrm{H}$-thymidine were found to be G6E3-positive. The percentage of mitotic cells found in these experiments closely agrees with previous ${ }^{3} \mathrm{H}$-thymidine studies of the developing rat hippocampal formation (Bayer and Altman, 1974; Schlessinger et al., 1975). In control experiments, cells from pups whose mothers had not been injected with ${ }^{3} \mathrm{H}$ thymidine were never associated with autoradiographic grains, and only cell suspensions incubated with G6E3 contained fluorescent cells. These results indicate that the antigen is expressed on nonmitotic (presumably postmitotic) cells.

Because G6E3 recognizes hippocampal neurons in tissue slices and neurons in primary hippocampal cultures, experiments were undertaken to analyze the immune reaction on acutely dissociated hippocampal cells from various ages with the use of a fluorescence-activated cell sorter (FACS). FACS analysis of freshly dissociated, unstained hippocampal tissue from embryos or early postnatal rat pups indicated the presence of 3 major forward-angle light-scatter peaks. When events from each peak were sorted and examined under the light microscope, it was found that the light-scatter peak nearest the origin (I) contained debris and subcellular elements; a low light-scatter peak (II) contained mostly dead cells, and a high light-scatter peak (III) contained live cells as determined by Trypan blue or propidium iodide staining (see St. John et al., 1986, for a description of FACS analysis and sorting of primary neuronal cells).

G6E3 staining of embryonic and early postnatal hippocampal cells resulted in a number of events that exhibited levels of fluorescence above control values in all 3 light-scatter peaks. Difference histograms of the data were generated as described in Materials and Methods and are shown in Figure 4. In an experiment with $16 \mathrm{~d}$ embryos, highly fluorescent cells were found in peaks II and III (Fig. 4A). When cells from 19-20 d embryos were analyzed, an even greater number of the highly fluorescent events were found in peak III (Fig. 4B). Staining of cells from 3-5 d neonates resulted in most of the fluorescent events falling in peaks I and II (Fig. 4C) with few events in peak 

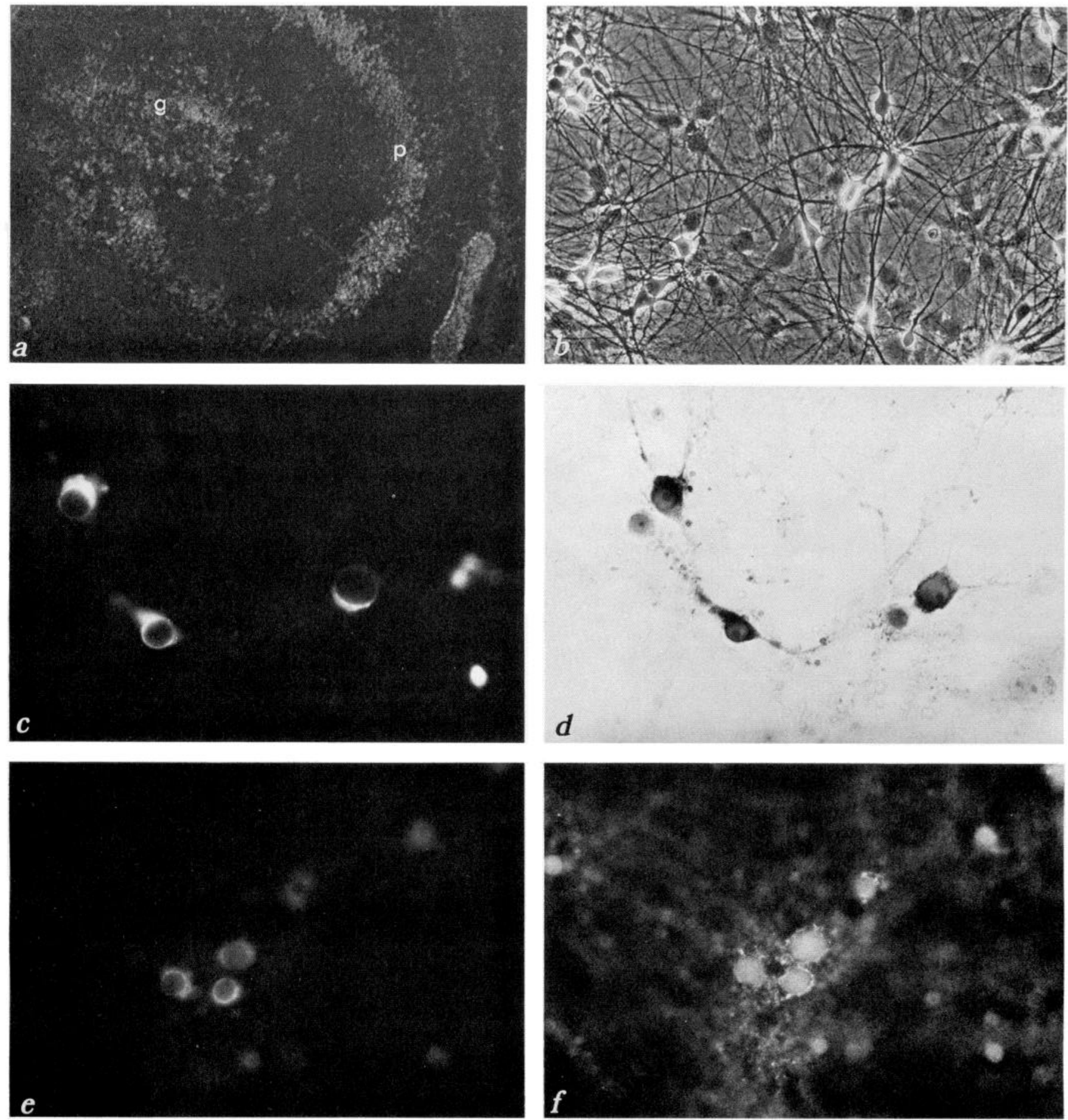

Figure 2. Monoclonal antibody G6E3 stains embryonic hippocampal neurons in tissue sections and in culture. $a$, Unfixed, frozen, $10 \mu \mathrm{m}$ section of 19-20 d embryonic rat brain stained sequentially with G6E3 and a fluoresceinated secondary antibody. Staining is apparent in the pyramidal cell layer $(p)$, as well as in the area of the developing dentate gyrus $(g)(\times 150)$. $b$, Phase-contrast photomicrograph of a 2.5 -week-old rat hippocampal culture. Neurons of various sizes and morphologies are evident on a confluent background of nonneuronal cell types $(\times 200)$. $c$, Three-week-old hippocampal culture stained with G6E3 followed by a fluoresceinated secondary antibody $(\times 360)$. A typical field of G6E3-positive cells was photographed, and the cultures were then processed for NSE reactivity. Visualization of specific staining was effected by the PAP method of Sternberger (1974). $d$, Same field as in $c$ showing that all G6E3-positive cells costain for NSE $(\times 360)$. $e$, Three-week-old hippocampal culture stained with G6E3 as in $c$. G6E3-positive cells are shown. The culture was then fixed and stained with anti-GAD antibodies followed by a rhodaminated secondary antibody $(\times 360)$. $f$, Same field as in $e$ showing that the G6E3-positive cells are surrounded by GAD-positive terminals $(\times 360)$.

III. The percentage of highly fluorescent events in peak III relative to the total number of events was calculated for $16 \mathrm{~d}$ embryos $(n=1), 19-20 \mathrm{~d}$ embryos $(n=4)$, and 3-5 d neonates $(n=4)$. The values obtained were $7,10 \pm 2 \%$, and $2 \pm 0.8 \%$
(SEM), respectively. The percentages of total events in peaks IIII in an experiment from each age group are given in the legend to Figure 4. Thus, under the conditions employed, embryonic day 20 appeared to be the optimal age for obtaining specifically 

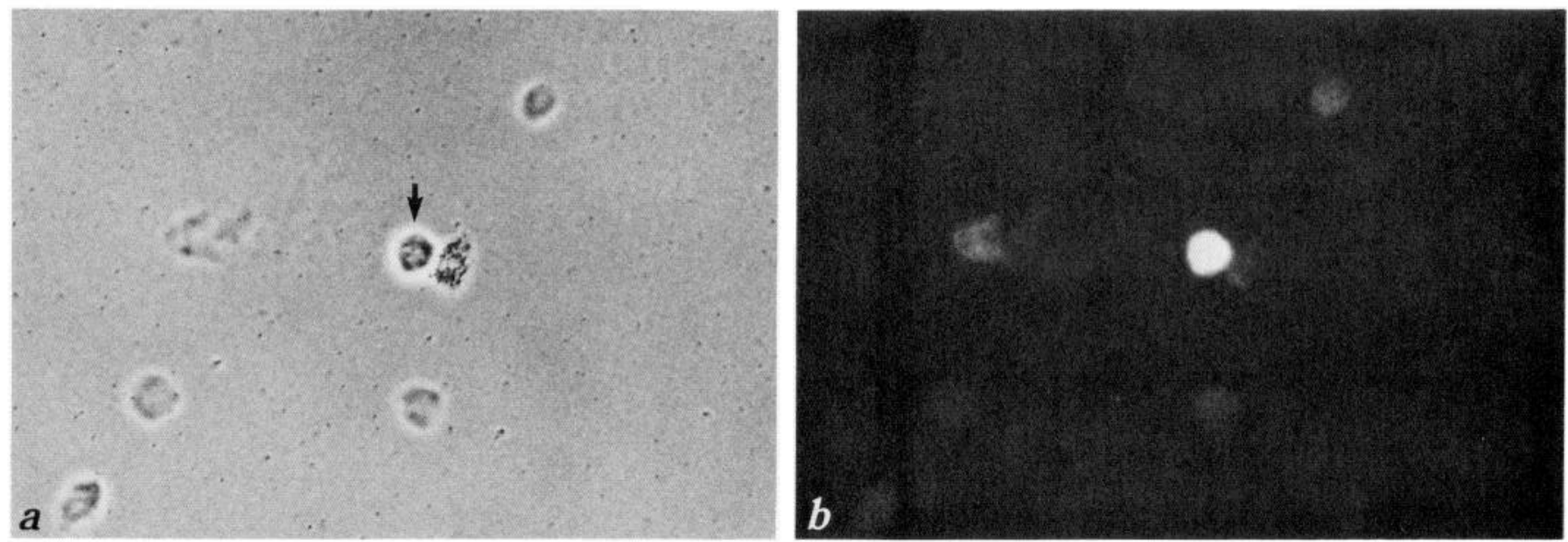

Figure 3. Hippocampal cells undergoing mitosis do not express $\mathrm{A}_{86}$. Hippocampal cells from $20 \mathrm{~d}$ embryonic rats whose mothers had been injected with ${ }^{3} \mathrm{H}$-thymidine $2.5 \mathrm{hr}$ prior to dissection were stained with $\mathrm{G} 6 \mathrm{E} 3$ and processed for autoradiography as described in the text. $a$, Phase-contrast photomicrograph showing an unlabeled cell (arrow) and an adjacent cell heavily labeled with silver grains. $b$, Fluorescence photomicrograph of the same field showing that only the unlabeled cell stained with G6E3 $(\times 360)$.

stained, live, hippocampal neurons. The FACS was used in 3 experiments to isolate a pure population of G6E3-positive neurons from $20 \mathrm{~d}$ embryos in order to maintain these cells in culture. Approximately $5 \times 10^{5}$ fluorescent events (corresponding to $2 \times 10^{5}$ cells) in peak III were sorted and $0.5-1.0 \times 10^{5}$ cells were plated per $35 \mathrm{~mm}$ plate. Sorted cells did not attach and survive on collagen- or poly(L-lysine)-coated substrata. Survival was obtained when sorted cells were grown on a confluent monolayer of nonneural hippocampal or cortical cells. In one case the cells were stained with G6E3 after a week in culture. All the neurons present restained positively for G6E3 (Fig. 5).

The specific binding of G6E3 to developing rat tissues appeared to be CNS-specific and substantially higher in embryonic brain than in the adult (Tables 1,2). It can also be seen that G6E3 bound nearly as well to murine brain as to rat brain (Table $2)$. In the reeler mutant $(+/+$, homozygous recessive), G6E3 binding was consistently lower than in reeler control $(+/-$, normal littermates) or Balb/c mouse brain. It is not known at

Table 2. Specific binding of G6E3 to various tissues measured by radioimmunoassay

Tissue

${ }^{125} \mathrm{I}-\mathrm{F}\left(\mathrm{ab}^{\prime}\right)_{2}(\mathrm{pmol})$ specifically bound/

Embryonic rat brain

$13 \mathrm{~d}$ mg protein ${ }^{a}$

$19 \mathrm{~d}$

Embryonic rat cerebellum, $19 \mathrm{~d}$

Adult rat

Hippocampus

Cerebellum

Liver

0.05

BALB/c (mouse; brain)

Reeler

$\left(\mathrm{B}_{6} \mathrm{C}_{3}\right.$; brain) $+/+$

$\left(\mathrm{B}_{6} \mathrm{C}_{3}\right.$; brain) $+/-$

${ }^{a}$ Each value is the average of at least 4 experiments. None of the values differed by more than $10 \%$. present if this was due to a reduction in the number of cells bearing $A_{g 6}$ or to a reduction in the concentration of $A_{86}$ per cell.

The biochemical nature of the antigen was also investigated. Monosaccharides (100 mM) and mixed bovine brain gangliosides (Sigma: $100 \mu \mathrm{g} / 0.2-0.4 \mathrm{mg}$ crude membrane pellet protein) were unable to block G6E3 binding in radioimmunoassay experiments (data not shown). However, at $500 \mathrm{~mm}$, D-galactose did inhibit G6E3 binding by $80 \%$, whereas other sugars (i.e., fucose, $N$-acetylgalactosamine, and $N$-acetylglucosamine) were still ineffective at this concentration, suggesting that $A_{g 6}$ is a glycoprotein with some glycose-moiety participation in the antigenic determinant recognized by G6E3. An immunoblot of adult rat hippocampus and cerebellum subjected to SDS-PAGE is shown in Figure 6. G6E3 recognized a single protein band in both tissues with an $M_{\mathrm{r}}=43,000$.

\section{Discussion}

With the monoclonal antibody G6E3, it has been possible to identify a cell-surface protein with a variety of properties that suggests it plays an important role in the development of the hippocampus and cerebellum. Moreover, it has been possible to isolate and maintain in culture a subpopulation of embryonic hippocampal neurons using G6E3 and a FACS.

G6E3 recognizes a single cell-surface protein found only in the dentate gyrus granule, hippocampal pyramidal, and cerebellar Purkinje neurons in the adult rat and may be developmentally regulated, probably appearing near the time when postmitotic neuroblasts have begun their migration. This conclusion is based on the fact that early in development (embryonic day 13), G6E3 recognizes cells in various brain regions and spinal cord. Also, the ${ }^{3} \mathrm{H}$-thymidine studies demonstrate that only nonmitotic cells express $A_{86}$.

Besides recognizing identifiable neurons in tissue sections, G6E3 also recognizes neurons in primary hippocampal cultures. Thus, it may be possible to characterize these cells pharmacologically and electrophysiologically, as well as to assess the role of $A_{86}$ in synapse formation in vitro.

G6E3 also recognizes cells from the hippocampus and cerebellum of several strains of mice. Various inbred strains of mice and neurological mutants are available, affording other opportunities to address the possible function of $\mathrm{A}_{86}$. For example, G6E3 reacts with the reeler mutant (Falconer, 1951). In both the cerebellum and the hippocampal formation, the number of 


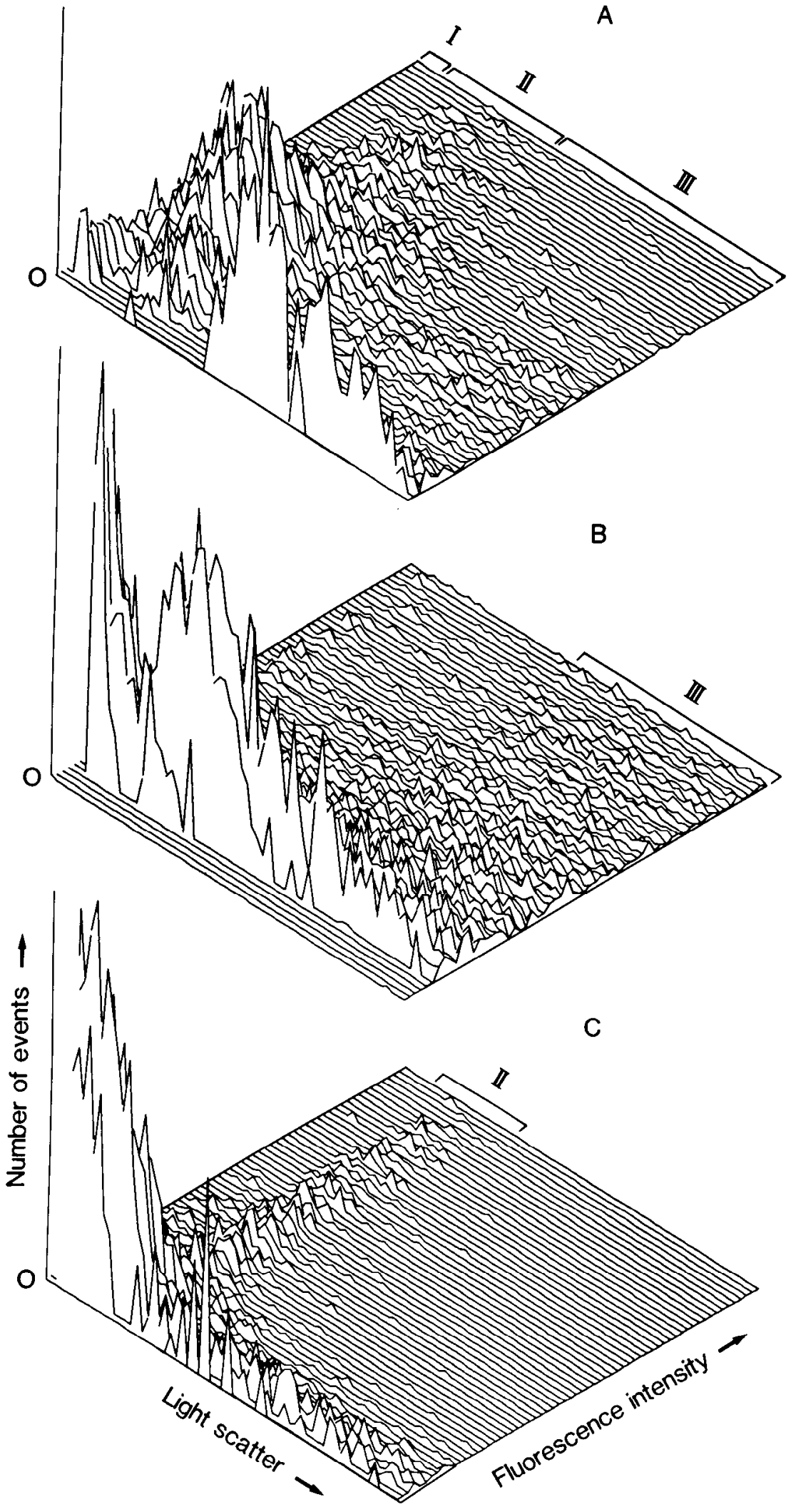

Figure 4. Difference histograms of cell counts as a function of their light scatter and fluorescence generated by FACS analysis of hippocampal cells stained with G6E3. Difference histograms were obtained by subtracting control values from experimental values. See Results for a complete description of how the histograms were generated. $A$, Sixteen day embryonic rat hippocampus. Of the total number of events fluorescent above control levels (positive events), $7.4 \%$ were found in peak II and $7.2 \%$ were found in peak III. $B$, Twenty day embryonic rat hippocampus. Peak II contained $7 \%$ and peak III contained $12 \%$ of the positive events. At this developmental age the majority of the fluorescent events appear in peak III. $C$, Four day postnatal hippocampus. Five percent of the positive events are found in the dead-cell peak (peak II), whereas only $2 \%$ of the positive events are found in the live cell peak (peak III). At all ages analyzed, the majority of the light-scatter events are in the peak containing debris (peak I near the origin) or are cells (events) that do not exhibit fluorescence above background (control) levels.

granule cells is reduced in these mice (Mariani et al., 1977; Stanfield and Cowan, 1979). However, the most interesting feature of the reeler brain is the marked malpositioning of neurons. This abnormality may be due to alterations in cell-surface molecules necessary for proper neuronal positioning during devel- opment (Goffinet, 1984). The reduction in immunoreactivity in the reeler hippocampus relative to controls suggests that $A_{86}$ could be one of the molecules that play a role in this phenomenon. Particularly if the reduction is present on individual Purkinje and/or pyramidal neurons and not merely a reflection of 


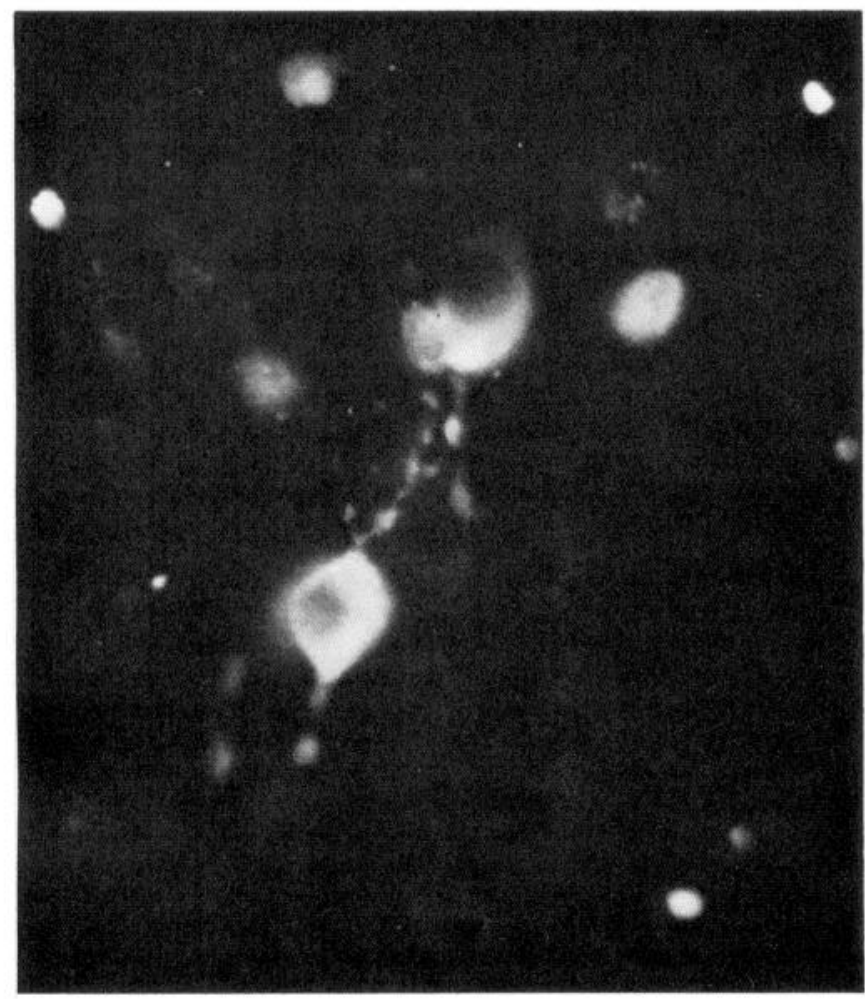

Figure 5. Example of sorted, G6E3-positive cells in culture. In this study, $20 \mathrm{~d}$ embryonic hippocampal neurons were isolated by fluorescence-activated cell sorting, maintained in culture for $7 \mathrm{~d}$, and then restained with G6E3. All sorted neurons displayed G6E3-positive fluorescence $(\times 360)$.

reduced populations of granule cells. At any rate, G6E3 labeling of cells in concert with cell sorting may make it possible to isolate pure neuronal populations from reelers and other neurological mutants and make direct comparisons at the molecular level between affected cells and the appropriate controls.

We have consistently found a highly fluorescent dead-cell peak whenever cell suspensions are incubated with antibodies for FACS analysis. These could be dead cells that bound or took up antibodies nonspecifically, or dead cells that retained antigenicity and thus bound the antibody specifically. They could also be cells that were killed after specific antibody binding either by exposure to the cold or to antigen-antibody complexes formed at the cell surface. Although the number of dead cells does increase when cells are incubated on ice, G6E3 alone does not appear to be cytotoxic at 25 or $37^{\circ} \mathrm{C}$ (in the absence of complement). When cells in cultures were exposed to the antibody at these temperatures, there was no increase in the number of cells that stained with Trypan blue or propidium iodide when compared to cells not exposed to the antibody. Nevertheless, the antibody could still facilitate cell death at low temperatures. For example, extensive cross-linking of antigen-antibody complexes in the plasma membrane could adversely affect many membrane-associated functions, rendered more labile by the reduced temperature.

We have encountered several difficulties in analyzing and sorting antibody-labeled cells. In some cases, the recovery of live, labeled cells is quite low $(1-2 \%$ as opposed to $10-12 \%$ of the total events). The plating efficiency of the sorted cells is also low $(10-50 \%)$. These problems could be due to exposure to low temperatures or to cross-linking on the cell surface in addition to laser damage or suboptimal culture conditions. Experiments

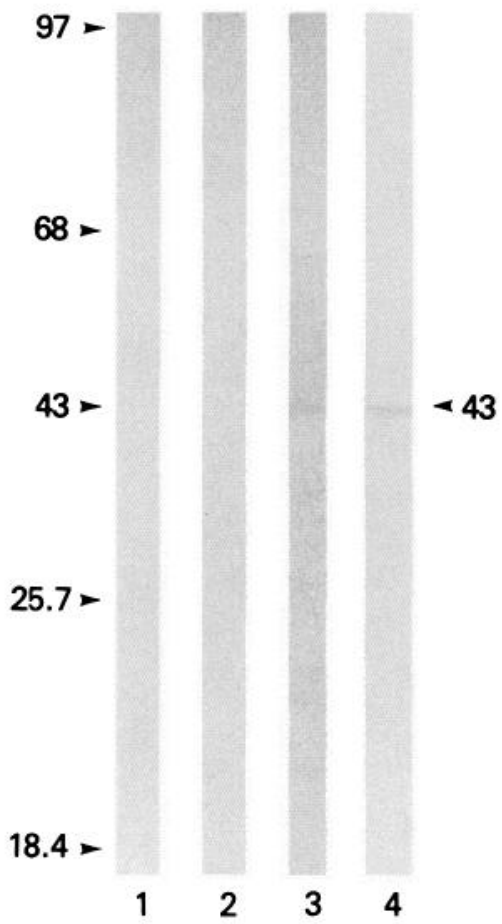

Figure 6. Identification of G6E3-specific proteins by immunoblot analysis. Lanes 1 and 2 (controls) are adult rat hippocampal and cerebellar proteins, respectively, incubated with hybridoma tissue culture medium (RPMI plus $15 \%$ fetal bovine serum) minus monoclonal antibody. Lane 3, Immunoblot of adult rat hippocampal proteins stained with G6E3 hybridoma conditioned medium. Lane 4, Immunoblot of adult rat cerebellum stained with G6E3 hybridoma conditioned medium.

are in progress to increase the number of G6E3-positive cells and improve their survival in vitro.

In conclusion, we have demonstrated that a strategy consisting of (1) using a defined brain structure for the generation of monoclonal antibodies, and (2) screening for regional specificity in thin sections, followed by (3) screening in primary cultures or in the FACS for cell-surface binding and neuronal specificity, can lead to the isolation of antigenically homogeneous populations of cells that can be maintained in culture for further investigation.

\section{References}

Barnstable, C. J. (1980) Monoclonal antibodies which recognize different cell types in the rat retina. Nature 286: 231-235.

Bartlett, P. F., M. D. Noble, R. M. Pruss, M. C. Raff, S. Rattray, and C. A. Williams (1981) Rat neural antigen-2 (RAN-2): A cell surface antigen on astrocytes, ependymal cells, Muller cells and lepto-meninges defined by a monoclonal antibody. Brain Res. 20: 339-351.

Batteiger, B., V. W. J. Newhall, and R. B. Jones (1982) The use of Tween 20 as a blocking agent in the immunological detection of proteins transferred to nitrocellulose membranes. J. Immunol. Methods 55: 297-307.

Bayer, S. A. (1980) Development of the hippocampal region in the rat. I. Neurogenesis examined with ${ }^{3} \mathrm{H}$-thymidine autoradiography. J. Comp. Neurol. 190: 87-114.

Bayer, S. A., and J. Altman (1974) Hippocampal development in the rat: Cytogenesis and morphogenesis examined with autoradiography and low-level X-irradiation. J. Comp. Neurol. 158: 55-80.

Bayer, S. A., J. W. Yackel, and P. S. Puri (1982) Neurons in the rat dentate gyrus granule layer substantially increase during juvenile and adult life. Science 216: 890-892.

Boyse, E. A., and H. Cantor (1979) Cellular communication and differentiation. Arthritis Rheum. 22: 1153-1160. 
Bradford, M. (1976) A rapid and sensitive method for the quantitation of microgram quantities of protein utilizing the principles of proteindye binding. Anal. Biochem. 72: 248-254.

Cohen, J., and S. Y. Selvendran (1981) A neuronal cell-surface marker is found in the CNS but not in peripheral neurons. Nature 291: 421423.

Cotman, C. W. (1976) Lesion-induced synaptogenesis in brain: A study of dynamic changes in neuronal membrane specializations. J. Supramolec. Struct. 4: 319-327.

Cotman, C. W., and J. V. Nadler (1978) Reactive synaptogenesis in the hippocampus. In Neuronal Plasticity, C. Cotman, cd., pp. 227271, Raven, New York.

Falconer, D. S. (1951) Two new mutants, 'Trembler' and 'Reeler', with neurological actions in the house mouse. J. Genet. 50:192-201.

Galfre, G., S. C. Howe, C. Milstein, G. W. Butcher, and J. C. Howard (1977) Antibodies to major histocompatibility antigens produced by hybrid cell lines. Nature 266: 550-552.

Giloh, H., and J. W. Sedat (1982) Fluorescence microscopy: Reduced photobleaching of rhodamine and fluorescein protein conjugates by n-propyl gallate. Science 217: 1252-1255.

Goffinet, A. M. (1984) Events governing organization of postmigratory neurons: Studies on brain development in normal and reeler mice. Brain Res. Rev. 7: 261-296.

Hawkes, R., E. Niday, and A. Matus (1982) Monoclonal antibodies identify novel neural antigens. Proc. Natl. Acad. Sci. USA 79: 24102414.

Hood, L., H. V. Huang, and W. J. Dryer (1977) The area-code hypothesis: The immune system provides clues to understanding the genetic and molecular basis of cell recognition during development. J. Supramol. Struct. 7: 531-559.

Kapatos, G., M. Caserta, and J. L. Barker (1983) A monoclonal antibody produced by in vitro immunization against clonal pituitary cells recognizes a surface protein on specific populations of neurons in the mouse CNS. J. Neurosci. Abstr. 9: 343.

Kiss, J. Z., E. Mezey, and L. Skirboll (1984) Corticotropin-releasing factor-immunoreactive neurons of the paraventricular nucleus become vasopressin positive after adrenalectomy. Proc. Natl. Acad. Sci. USA 81 : 1854-1858.

Kohler, G., and C. Milstein (1976) Derivation of specific antibodyproducing tissue culture and tumor lines by cell fusion. Eur. J. Immunol. 6: 511-519.

Kosaka, T., K. Hama, and J.-Y. Wu (1984) GABAergic synaptic boutons in the granule cell layer of rat dentate gyrus. Brain Res. 293. 353-359.

Koulakoff, A., B. Bizzini, and Y. Berwald-Netter (1983) Neuronal acquisition of tetanus toxin binding sites: Relationship with the last mitotic cycle. Dev. Biol. 100: 350-357.

Laemmli, U. K. (1970) Cleavage of structural proteins during the assembly of the head of bacteriophage T4. Nature 227: 680-685.

Mariani, J., F. Crepel, K. Mikoshiba, J. P. Changeaux, and C. Sotelo (1977) Anatomical, physiological and biochemical studies of the cerebellum from reeler mutant mouse. Phil. Trans. R. Soc. Lond. [Biol.] 281: 1-28.

Marangos, P. J., C. Zomzely-Neurath, and C. York (1975) Immunological studies of a nerve specific protein (NSP). Arch. Biochem. Biophys. 170: 289-293.
McKay, R., and S. V. Hockfield (1982) Monoclonal antibodies distinguish antigenically discrete neuronal types in the vertebrate central nervous system. Proc. Natl. Acad. Sci. USA 79: 6747-6751.

Oertel, W. H., D. E. Schmechel, E. Mugnaini, M. L. Tappaz, and I. J. Kopin (1981) Immunocytochemical localization of glutamate decarboxylase in rat cerebellum with a new antiserum. Neuroscience 6 : 2715-2735.

Palkovits, M., and M. J. Brownstein (1983) Microdissection of brain areas by the punch technique. In Methods in Neuroscience, Microdissection Techniques, A. C. Cuello, ed., pp. 1-36, Wiley, Chichester, UK.

Roseman, S. (1974) The biosynthesis of cell-surface components and their potential role in intercellular communication. In The Neurosciences Third Study Program, F. O. Schmitt and F. G. Worden, eds., pp. 795-804, MIT Press, Cambridge.

Romijn, H. J., F. van Huizen, and P. S. Wolters (1984) Toward an improved serum-free chemically defined medium for long-term culturing of cerebral cortex tissue. Neurosci. Behav. Rev. 8: 301-334.

Schachner, M. (1982) Cell type specific antigens in the mammalian nervous system. J. Neurochem. 39: 1-8.

Schlessinger, A. R., W. M. Cowan, and D. I. Gottlieb (1975) An autoradiographic study of the time of origin and the pattern of granule cell migration in the dentate gyrus of the rat. J. Comp. Neurol. 159: 149-175.

Schlessinger, A. R., M. W. Cowan, and L. W. Swanson (1978) The time of origin of neurons in Ammon's horn and the associated retro hippocampal fields. Anat. Embryol. 15: 153-173.

Schmechel, D. E., M. W. Brightman, and J. L. Barker (1980) Localization of neuron-specific enolase in mouse spinal neurons grown in tissue culture. Brain Res. 181: 391-400.

Segal, M. (1983) Rat hippocampal neurons in culture: Responses to electrical and chemical stimuli. J. Neurophysiol. 50: 1249-1264.

Sperry, R. W. (1963) Chemoaffinity in the orderly growth of nerve fiber patterns and connections. Proc. Natl. Acad. Sci. USA 50: 703710.

Stanfield, B. B., and W. M. Cowan (1979) The morphology of the hippocampus and dentate gyrus in normal and reeler mice. J. Comp. Neurol. 185: 393-422.

Sternberger, L. A. (1974) Immunocytochemistry, Prentice-Hall, Englewood Cliffs, NJ.

St. John, P. A., W. M. Kell, J. S. Mazzetta, G. D. Lange, and J. L. Barker (1986) Analysis and isolation of embryonic mammalian neurons by fluorescence-activated cell sorting. J. Neurosci. 6: 1492-1512.

Towbin, H., T. Staehelin, and J. Gordon (1979) Electrophoretic transfer of proteins from polyacrylamide gels to nitrocellulose sheets: Procedure and some applications. Proc. Natl. Acad. Sci. USA 76: 4350 4354.

Trisler, G. D., M. D. Schneider, and M. Nirenberg (1981) A topographic gradient of molecules in retina can be used to identify neuron position. Proc. Natl. Acad. Sci. USA 78: 2145-2149.

Tyler, A. (1947) An auto-antibody concept of cell structure, growth and differentiation. Growth (Suppl.) 10: 7-19.

Weiss, P. (1947) The problem of specificity in growth and development. Yale J. Biol. Med. 19: 235-278. 